\title{
PEMBERDAYAAN PENGUSAHA KECIL DAN MENENGAH MELALUI KEPEMILIKAN SERTIFIKAT MEREK
}

\section{(EMPOWERMENT OF SMALL AND MEDIUM ENTREPRENEURS THROUGH BRAND CERTIFICATE OWNERSHIP)}

\author{
Agung Sujatmiko ${ }^{1}$, Fiska Silvia $\mathbf{R R}^{2}$ \\ ${ }^{1,2}$ Departemen Perdata Fakultas Hukum Universitas Airlangga \\ e-mail: agung.sujatmiko@fh.unair.ac.id
}

\begin{abstract}
The legal protection for trademark in Indonesia is regulated in Law Number 20 Year 2016. According to the legal system which has adopted, this Act requires that legal protection of trademark available to be obtained through the registration, on the other words that there is an obligation for the owners to register their own trademarks. In fact, several small and medium entrepreneurs (SMEs) in Kediri still do not have awarnesse to register their own trademark yet, due to lack of the literation about the legal system of trademark, the procedure and its application. Unfortunately, it is common for the SMEs in Kediri used to use the other parties' trademark without any permission. The application of the trademark without permission is a violation in the perspective of intellectual property law. This situation will be facing the dispute among the parties, especially the claim from the genuine trademark owner who have registered their trademark first. The dispute will spend the time, energy and alot of money. For this reason, it is necessary to do a community service as assistance or accompaniment action, namely assist the SMEs in Tofu Industries in order to register the trademark which apply at Kediri Regency. The main goal of this community service is the SMEs will have legal awareness about the ownership of trademark certificate.
\end{abstract}

Keywords: legal system, registration procedure, the certificate of trademark, the trademark right.

abstrak

Perlindungan hukum atas merek di Indonesia diatur dalam Undang-undang Nomor 20 Tahun 2016. Berdasar sistem konstitutif yang dianut, undang-undang itu mensyaratkan bahwa perlindungan hukum atas merek bisa diperoleh melalui pendaftaran, artinya ada kewajiban bagi pemilik merek untuk mendaftarkan mereknya. Banyak pengusaha kecil dan menengah di Kediri belum memiliki merek sendiri, sehingga tidak jarang menggunakan merek pihak lain tanpa izin. Penggunaan merek tanpa izin merupakan pelanggaran. Untuk itu itu perlu dilakukan pendampingan pendaftaran merek bagi pengusaha kecil dan menengah di bidang Tahu di Kabupaten Kediri. Penggunaan merek sendiri akan menunjang pendapatan pelaku usaha kecil dan menenngah. Hal itu didapat dari penggunaan merek yang aman dan bebas dari gugatan pihak lain yang sangat menyita waktu, tenaga dan uang. Atas dasar itu, penganbdian masyarakat ini dilakukan dengan menggunakan metode sosialisasi tentang fungsi pendaftaran merek dan manfaat sertifikat merek. Selain sosialisasi dilakukan juga pendampingan pengurusan sertifikat merek. Tujuannya agar para pengusaha kecil dan menengah memiliki kesadaran hukum tentang pentingnya kepemilikan sertifikat merek.

Kata Kunci : hak merek, pendaftaran, system konstitutif, sertifikat merek. 


\section{PENDAHULUAN}

Melalui Undang-undang Nomor 20 Tahun 2016, pemerintah telah memulai sistem pendaftaran merek yang terintegrasi secara on line dengan beberapa Negara di dunia dengan memberikan kemudahan akses pendafataran. Pendaftaran merek tersebut wajib dilakukan mengingat system yang dianut adalah system konstitutif (first to file principle). Jika tidak dilakukan pendaftaran, maka hak merek tidak dilindungi oleh Negara. Pada sisi lain banyak pengusaha kecil dan menengah (UKM) yang belum mendaftarkan mereknya.

Hak merek sebagai salah satu bagian Hak Kekayaan Intelektual (HKI) memiliki fungsi yang penting dalam dunia perdagangan, ia tidak saja menjadi pembeda antara barang dan atau jasa sejenis, tetapi juga berfungsi sebagai alat untuk memenangkan persaingan dalam merebut pasar konsumen. Di samping itu, suatu merek yang telah menjadi merek terkenal juga berfungsi sebagai goodwill dan asset perusahaan yang tidak ternilai harganya

Atas dasar alasan tersebut hak merek perlu dilindungi. Konsep perlindungan hukum terhadap hak merek tersebut mengacu pada sifat hak merek yang bersifat khusus (exclusive). Hak kebendaan yang sifatnya monopoli tersebut dapat dipakai oleh orang lain dengan izin dari pemilik merek

Sesuai dengan Undang-undang Nomor 20 Tahun 2016 tentang Merek dan Geografis (selanjutnya disingkat UUM), sertifikat merek dapat diperoleh dengan cara pendaftaran merek. Pendaftaran merek merupakan suatu kewajiban bagi seorang/pengusaha agar hak mereknya dilndungi oleh Negara. Jika mereknya tidak terdaftar, maka mereknya tidak mendapatkan perlindungan hukum, yang berakibat bisa menimbulkan persoalan hukum dengan pihak lain. Untuk itu, maka para pengusaha kecil dan menengah di bidang Tahu di Kabupaten Kediri seharusnya mempunyai sertfikat merek sendiri, supaya dapat melaksanakan bisnisnya dengan aman dan legal. Selama ini banyak dari pelaku usaha kecil dan menengah di bidang Tahu yang berpotensi terjadinya gugatan oleh pemilik merek yang dirugikan. Untuk mengatasi problem tersebut bisa digunakan penggunaan merek sendiri yang disediakan oleh undang-undang. Atas dasar itu, maka akan dilakukan suatu pengabdian terkait dengan pendampingan pengurusan sertifikat pengusaha kecil dan menengah di bidang Tahu di Kabupaten Kediri.

Pada tahap awal dilakukan pemetaan pengusaha yang belum memiliki merek, kemudian dipanggil untuk diberikan sosialisasi tentang fungsi pendaftaran merek dan fungsi sertifikat merek. Tujuannya agar para pengusaha kecil dan menengah memahami dan melaksanakan pendaftaran merek yang diharuskan oleh undang-undang.

Sesuai dengan konsep yang ada tujuan pendaftaran tersebut sebagai implementasi system konstitutif yang dianut oleh undang-undang merek. Kalau suatu merek didaftarankan dan pendaftarannya diterima akan memperoleh perlindungan hukum selama sepuluh tahun dan dapat diperpanjang tanpa batas, dengan syarat mereknya masih digunakan dan barangnya masih diproduksi. Jika berhasil mendapatkan sertifikat merek, maka akan sangat membantu pengusaha dalam memasarkan produknya, tanpa dihantui problematika gugatan tentang pelanggaran merek dari pihak lain. 


\section{METODE PENGABDIAN MASYARAKAT}

Pertama dilakukan sosialisasi tentang manfaat sertifikat merek sebagai sarana perlindungan hukum bagi pengusaha.

Kedua, pendampingan dan bimbingan teknis dalam pengurusan sertifikat merek ke kantor Direktorat Jenderal Kekayaan Kementrian Hukum dan HAM RI.

Monitoring hasil pengurusan sertifikat merek Asistensi jika timbul masalah dalam pengurusan sertifikat merek.

\section{HASIL DAN PEMBAHASAN}

Pengurusan kepemilikan sertifikat merek menjadi sangat penting, mengingat itu merupakan alat bukti yang sangat kuat untuk mempertahankan hak kepemilikannya jika terjadi sengketa di pengadilan. Itu merupakan system yang dianut oleh Undang-undang Nomor 20 Tahun 2016 tentang Merek (UUM) yang mendasarkan pada prinsip pendaftaran (first to file). Hasil yang diharapkan adalah terciptanya perilaku pengusaha kecil dan menengah tertib pada kewajiban pendaftaran merek. Pengabdian ini perlu dilakukan karena berdasarkan data yang ada kepemilikan sertifikat merek masih relative sedikit, artinya pendaftaran merek yang diwajibkan oleh undang-undang belum dilaksanakan dengan baik oleh pengusaha kecil dan menengah. Hal itu disebabkan karena berbagai kendala teknis dan yuridis. Kendala teknisnya berupa ketidaktahuan bagaimana tata cara pendaftaran merek, sedangkan kendala yuridisnya terkait kurangnya kesadaran hukum terhadap perlindungan hukum hak merek melalui pendaftaran. Pada akhirnya kegunaan pengabdian ini sangat mendukung rencana strategis penelitian di bidang pengembangan sumber daya manusia terkait dengan pelaku usaha bi bidang tahu yang dilakukan oleh Usaha Kecil dan Menengah (UKM) di Kabupaten Kediri.

Program ini telah sampai pada tahapan kedua, karena tahapan pertama telah dilaksanakan dengan baik dan lancar pada tanggal 02 Agustus 2018 pukul 09.00 yang dihadiri oleh tim pengmas dari Fakultas Hukum Universitas Airlangga, Tim Penyuluh dari Kantor Dinas Industri dan Perdagangan Kabupaten Kediri, 30 (tiga puluh) UMKM di bawah bimbingan Kantor Dinas Industri dan Perdagangan Kabupaten Kediri. Kemudian Pada Tanggal 23 Oktober 2018 dilakukan pendampingan penulisan formulir pendaftaran merek dan melengkapi persyaratan lainnya, seperti Etiket Merek, KTP, NPWP dan sebagainya.

Solusi yang ditawarkan dan pelaksanaan program oleh Tim Pengmas FHUA meliputi tahapan lengkap sebagaimana berikut : Pertama dilakukan sosialisasi tentang manfaat sertifikat merek sebagai sarana perlindungan hukum bagi pengusaha.Kedua, pendampingan dan bimbingan teknis dalam pengurusan sertifikat merek ke kantor Direktorat Jenderal Kekayaan Kementrian Hukum dan HAM RI. Monitoring hasil pengurusan sertifikat merek, Asistensi jika timbul masalah dalam pengurusan sertifikat merek.

Harapan tim pengmas, program ini dapat mencapai tahapan akhir berupa realisasi target luaran program yang mencakup artikel pada jurnal non terakreditasi nasional atau media 
massa cetak nasional (koran). Laporan hasil kegiatan yang dilaporkan pada repository Universitas Airlangga serta luaran berupa Penggunaan sertifikat dan perlindungan hukum merek bagi pengusaha tahu di Kabupaten Kediri.

Target pengabdian ini adalah para pengusaha mengetahui tata cara pengurusan sertfikat merek (kolektif). Sedangkan luarannya adalah para pengusaha Tahu memiliki sertifikat merek sendiri.

Pada umumnya pengusaha Tahu di Kediri sudah memiliki merek lokal dan merek tersebut merupakan mereknya sendiri. Merek yang dipergunakan tersebut belum terdaftar pada Direktorat Jenderal Kekayaan Intelektual Kementrian Hukum dan HAM RI. Sementara Undang-ndang Merek Nomor 20 Tahun 2016 mewajibkan untuk pendaftaran merek.

Kewajiban bagi pemakai merek, agar mereknya didaftarkan agar mendapatkan perlindungan dari Negara. Para pengusaha Tahu di Kabupaten Kediri, sebagai pengguna merek, harus mendaftarkan mereknya . Kewajiban pendaftaran tersebut, merupakan konsekuensi stelsel konstitutif yang dianut dalam Undang-undang Merek Nomor 20 Tahun 2016. Jika kewajiban tersebut tidak dilaksanakan, maka mereknya tidak dilindungi oleh Negara.

Atas dasar itu, maka dilakukan program pengabdian ini dengan tujuan memberikan pendampingan pengurusan pendaftaran merek (kolektif), karena pada umumnya, para pengusaha tidak mengetahui bagaimana prosedur pendaftaran merek.

Dari pendampingan yang dilakukan, telah ada usaha dari mereka untuk mengurus pendaftaran merek antara lain merek Dak Tu Tong, Srikandi, Poo dan sebagainya. Usaha itu, mendapatkan bantuan dari Dinas Perdagangan dan Industri Kabupaten Kediri.

Hasil yang telah dicapai pada akhir pengabdian, telah dikirimkan pendaftaran merek sebanyak 20 pendaftar ke Direktorat Jenderal Kekayaan Intelektual di Jakarta untuk mendapatkan sertifikat merek. Proses pendaftaran tersebut memakan waktu kurang lebih setahun.

\section{PENUTUP}

\section{Simpulan}

Sertifikat merek merupakan alat bukti yang paling kuat dalam bidang kepemilikan hak merek. Sertifikat merek diperoleh melalui pendaftaran merek dengan disertai syaratsyarat yang sesuai dengan undang undang merek. Tanpa adanya sertifikat merek, kepemilikan merek masih belum sah dan kuat.

\section{Saran}

Sosialisasi tentang Undang-undang Merek perlu dilakukan secara rutin dan berkesinambungan terhadap semua stake holder yang bergerak di bidang perdagangan barang dan atau jasa, agar mereka sadar hukum terhadap pentingnya sertifikat merek. 


\section{DAFTAR PUSTAKA}

Sujatmiko, Agung Et.All, 2016, Penggunaan Prinsip Hukum Kontrak Dalam Perjanjian, Lisensi Merek Terkenal di Indonesia, Laporan Penelitian Unggulan Perguruan Tinggi.

, 2017, Prinsip Hukum Perlindungan Merek Dalam menunjang Peningkatan Industri Kreatif, Laporan Penelitian RKAT Fakultas Hukum Universitas Airlangga, Surabaya.

Agung Sujatmiko dan Ari Kurniawan, 2016, Prinsip Hukum Penyelesaian Sengketa Hak Merek dari Persetujuan TRIPs, Laporan Penelitian RKAT Fakultas Hukum..

Undang-undang Nomor 20 Tahun 2016 tentang Merek (LNRI Tahun 2016 Nomor 252, Tambahan Lembaran Negara Nomor 5953 